Barbara Šega - Čeh

Filozofska fakulteta

Ljubljana

\title{
PROPERCIJEVA ELEGIJA IN AVGUSTOVA MORALNA DRŽAVA
}

V mnogih stoletjih se je zvrstilo že nešteto ugibanj o tem, kdo so pravzaprav bile elegične ljubimke. Te skrivnostne opevane ženske so se $\mathrm{v}$ rimski elegiji razkrivale $\mathrm{v}$ najrazličnejših podobah, ki pa so praviloma dovolj zabrisane in zastrte, včasih celo kontradiktorne, da s svojo neprepoznavnostjo burijo bralčevo domišlijjo. So bile junakinje rimske ljubezenske elegije resnično le meretrices ${ }^{1}$, osvobojenke, ženske nižjega rodu, kot kažejo nekateri namigi v posameznih elegičnih pesmih, ali pa je bila ta krinka le običajen, tako rekoč predpisan pesniški obrazec, ki naj bi po eni strani bralce in poslušalce ljubezenske poezije pritegnil z vznemirljivostjo prepovedanega sadu, po drugi pa pesnike, ki so morda kršili uveljavljene moralne norme ali pa kot ljubljenci rimskega občinstva $\mathrm{k}$ takim kršitvam spodbujali, zavaroval pred ostrimi sankcijami Avgustove zakonodaje?

Že v obdobju republike je bilo mogoče tu in tam zaznati nekatere pobude za uveljavitev strogih zakonskih meril, ki naj bi v dobro države korenito posegla $\mathrm{v}$ zasebno življenje rimskih državljanov ${ }^{2}$. Po eni strani je šlo za golo zgražanje nad razvratnimi navadami, ki so se v primerjavi $z$ nekdanjimi plemenitimi in asketskimi mores maiorum čezmerno razpasle, po drugi pa zahteve po omejevanju razvrata (comprimendae libidines) in spodbujanju rojstev (propaganda proles) že lahko razumemo kot zametke nove demografske politike, iz katerih je pozneje zrasla Avgustova moralna reforma. Avgustov zakon, ki so ga različni pisci poimenovali Lex Iulia de adulteriis, de adulteriis coercendis, de adulteriis et de stupro, de pudicitia, de adulteriis et de pudicitia ${ }^{3}$, je najverjetneje stopil v veljavo leta 16, kar potrjuje tudi Horacij v eni od svojih pesmi ${ }^{4}$, $\mathrm{ki} \mathrm{je} \mathrm{predvidoma} \mathrm{nastala} \mathrm{leta} 14$ ali na začetku leta 13 . Isti zakon v nekakšnem paradoksalnem kontekstu omenja tudi Ovidij:

\footnotetext{
${ }^{1}$ Cf. Paul Veyne, Rimska erotična elegija, Lj. 1992. Izraz meretrix gre razumeti tako, kot ga definira Cicero $v$ Pro Caelio, 49,9: Si quae non nupta mulier domum suam patefecerit omnium cupiditati palamque sese in meretricia vita conlocarit, virorum alienissimorum conviviis uti instituerit, si hoc in urbe, si in hortis, si in Baiarum illa celebritate faciat, si denique ita sese gerat non incessu solum sed ornatu atque comitatu, non flagrantia oculorum, non libertate sermonum, sed etiam complexu, osculatione, actis, navigatione, conviviis, ut non solum meretrix sed etiam proterva meretrix procaxque videatur: cum hac si qui adulescens forte fuerit, utrum hic tibi, L. Herenni, adulter an amator, expugnare pudicitiam an explere libidinem voluisse videatur? Po njegovi definiciji torej meretrix ni nujno ženska, ki prodaja svoje telo, ampak spogledljivka in razuzdanka.
}

2 Cf. Susan Treggiari, Roman marriage, Iusti coniuges from the time of Cicero to the time of Ulpian, Oxford University Press, New York 1993. Cic., Marc. 23: Omnia sunt excitanda tibi, C. Caesar, uni quae iacere sentis belli ipsius impetu, quod necesse fuit, perculsa atque prostrata: constituenda iudicia, revocanda fides, comprimendae libidines, propaganda suboles, omnia quae dilapsa iam diffluxerunt severis legibus vincienda sunt.

${ }^{3}$ Cr. id., str.278, op. 86.

${ }^{4}$ Hor., C. 4,5,20-24: nullis polluitur casta domus stupris, mos et lex maculosum edomuit nefas, laudantur simili prole puerperae, culpam poena premit comes.

orej mogoðe, da je bil zakon, ki je sankcioniral nezgleden način življenja, ucinkovit, vsaj po presoji bvornikov. 
S kakšno ukano lahko prelisičiš moža, ki pretkan je, s kakšno čuvarja oko, skoraj sem že zamolčál.

Ženo naj strah bo moža; skrbno naj bo nadzorovana; prav je tako, to veli zakon in cesar in sram.

Kdo pa trpel bi, da ti, ki si komaj svobodo dobila, tudi čuvarja imaš? Pridi, naučim te prevar! ${ }^{5}$

Omenjene verze, ki jih Ovidij s prozorno lažno ironijo zelo neprepričljivo naslavlja izključno na lahkožive osvobojenke, so seveda lahko prebirale tudi matronae stolatae. In da so tudi te prav tako kot rimski elegiki dobro poznale zakonodajo, dokazuje Vistilijin primer: ugledna ženska iz pretorske družine, $\mathrm{ki}$ je imela sedem otrok in bila šestkrat poročena, se je dala zapisati med prostitutke, da bi se izognila predpisani kazni, ki je predvidevala za prešuštnice zaplembo polovice dote in tretjine premoženja ter izgon na enega izmed otokov, za prešuštnike pa zaplembo polovice imetja ter izgon na drug otok ${ }^{6}$. Ovidijeva pretresljiva usoda torej ne preseneča: očeta domovine je v svojem lahkotnem pesniškem samoljubju posmehljivo zbodel na najobčutljivejšem mestu - pri načrtnem in premišljenem snovanju veličastne državne moralne prenove.

Ko je Avgust leta 18 uveljavil Lex Iulia de maritandis ordinibus za spodbujanje porok in rojstev $^{7}$, ki je od državljanov zahteval popolno pokorščino tudi $v$ zasebnosti ${ }^{8}$ in jasno začrtal nenapisana pravila o razmejitvah med posameznimi stanovi, kakršna so doslej veljala samo za senatorje, pa še to povsem neuradno, je njegova poteza dvignila precej prahu. Zakon je namreč brezobzimo posegel tudi na čustveno področje, državljane silil k poroki, obenem pa prepovedoval poroke med svobodnimi državljani in prostitutkami, igralkami ter njihovimi potom $\mathrm{i}^{9}$. Negodovanje državljanov nad nesvobodno izbiro svojih zakonskih partnerjev je bilo očitno tako močno, da je moral Avgust zakon začasno umakniti ${ }^{10}$. Nad tem se radosti tudi Propercij v pesmi 2,7:

Radost gotovo obšla te je, Kintija, zakon je ukinjen, nekdaj nad njim sva solzé dolgo točila oba,

saj naju ločil bi ...

Propercijeva omemba Avgustove nravstvene reforme je sprožila vrsto polemik. Vprašati se je mogoče, kaj je v spletu resničnosti in domišljije, ki so ju v verzih nalašč neprepoznavno prepletali rimski elegiki, dejansko resničnega in kaj je od tega izmišljotina. Elegični pesniki se $v$ svojih elegijah načeloma niso poročali s svojimi ljubimkami in njihova ljubezen je bila večinoma neuslišana, Propercij pa se tokrat brez bojazni, da bi razblinil skrivnostni čar svoje nedosegljive izvoljenke, tako značilen za elegično poezijo, iskreno veseli, da so formalne ovire, ki bi utegnile preprečiti njegovo zakonsko zvezo s Kintijo, odstranjene.

Prej bi dovolil z vratu si sneti lastnega glavo, kakor pa bakle metal svatovske, kot vsi počno,

\footnotetext{
${ }^{3}$ Ov., Ars amatoria 3,611-614.

- Tac., Annales 2, 85, 1 sq. Pozneje so zakonsko vrzel, ki jo je skušala izkoristiti Vistilija, odpravili. Cf. S. Treggiari, Roman marriage, str. 297.

${ }^{7}$ Lex Papia Poppaea, ki je bil sprejet pet let pred Avgustovo smrtjo, je omenjeni zakon nekoliko ublažil in odpravil nekatere pomanjkljivosti.

${ }^{8}$ Cf. S. Treggiari, op. cit., str. $60-80$.

9 Tituli Ulpiani 13,2: Ingenui prohibentur ducere /corpore quaestum facientem/lenam et a lenone lenave manumissam et in adulterio deprehensam et iudicio publico damnatam et quae artem ludicram fecerit.

${ }^{10}$ Francesco della Corte, Le leges Iuliae e l'elegia romana, ANRW 2, 30, 1, 1982, str. 539-558.
} 
ali pa šel poročen mimo tvojih bi duri zaprtih, solzne upiral oči vanje, ki sem jih izdal. ${ }^{11}$

Iz Propercijevih vznesenih verzov je mogoče jasno sklepati, da ni bil zagovornik Avgustove moralne reforme, čeprav ga je Mecenat očitno večkrat snubil, naj se mu v duhu arhaičnih idealov pridruži na okopih cesarjevih prizadevanj za moralno restavracijo in politično konsolidacijo razpuščene rimske države. $V$ več pesmih (cf. 2,17 ) Propercij takim idealom obširno in vmes tudi pikro nasprotuje ${ }^{12}$. Če bi kdo vse skrunitve položil pod drobnogled, bi ugotovil, kot meni Propercij, da bi bil Rim lahko neznansko srečen, če bi lahko onečaščenje mores maiorum pripisali samo dekletom. Utemeljuje znano stališče, ki so ga zagovarjali vsi rimski elegični pesniki, češ da je hvalevredno umreti le od ljubezni ${ }^{13}$ in da sovražni vojščaki ne bodo ugledali njegove $\mathrm{krvi}^{14}$, kajti sam želi zmagovati zgolj na ljubezenskem bojišču:

Zame ta zmaga je bolj veličastna od zmage nad Parti, plen bo in kralji zamé, to zmagoslavni bo voz. ${ }^{15}$

Tudi v drugih pesmih $(1,1 ; 2,14)$ zavrača Mecenatovo ponudbo, naj pesni angažirano poezijo po cesarjevem naročilu, kot sta to počela Vergilij in Horacij.

... nikdar se nisi predal ljubezni, odkar si na svetu, vedno ti v mislih roji le domovina in boj, ...

Mene pa pusti, ki moč me usode že tlači, kar pomnim, naj živim tjavendan, dokler ne ustavi se dah.

Marsikdo dolgo užil je ljubezen in z radostjo umrl, mednje naj sodim še jaz, kadar prekrije me prst.

Nisem rojen za časti, pa tudi z orožjem ne spreten, volja usode je, naj bijem ljubezenski boj ${ }^{16}$.

Z Ovidijem, ki si je lahko zaradi svojega uglednega družbenega položaja privoščil več svobodomiselnosti kot Propercij, narekovala pa mu jo je seveda tudi njegova narava, sta bila glede elegičnega poslanstva nedvomno somišljenika.

Tudi kovanje zarot je tuje pesnikom svetim, daje podobo nravi lastne nam naša obrt.

Nismo ne častihlepni, sli po imetju ne vdani; ni nam politike mar, čislamo póstelj v temi. ${ }^{17}$

${ }^{11}$ Prop., 2,7.

12 Prop. 2, 32, 41: an quisquam in tanto stuprorum examine quaerit cur haec tam dives? quis dedit? unde dedit?'

o nimium nostro felicem tempore Romam, si contra mores una puella facit!

${ }^{13}$ Prop. 2, 17, 47-50. laus in amore mori: laus altera, si datur uno posse frui: fruar o solus amore meo,

[si memini, solet illa levis culpare puellas, et totam ex Helena non probat Iliada.]

\footnotetext{
${ }^{14}$ Prop. 2, 7.

15 Prop., 2, 14.

${ }_{16}$ Prop. 1, 6, 21-22; 25-30.

${ }^{17}$ Ov., Ars amatoria, 3, 539-542:
} 
Propercij je torej vsaj v prvih dveh knjigah svojih pesmi nepopustljivo vztrajal pri svojem. Deveta pesem tretje knjige pa že odseva nekoliko drugačno razpoloženje. Očitno so se pritiski na Propercija kar vrstili, kajti v tej pesmi sicer znova zagovarja svoja znana stališča, vendar ne več $s$ tako ognjevitim žarom. Vseh šestdeset verzov te pesmi je napisanih $s$ tehtnim premislekom, utemeljitve, še vedno precej podobne prejšnjim, pa zdaj zvenijo nekako opravičujoče in v njih ni več brezprizivne odločnosti, kakršna veje iz pesmi prve in druge knjige. Mogoče je slutiti, da je skušal pesnik na vsak način izbrskati prave argumente, ki bi lahko prepričali prijatelja, naj ga ne postavlja v vlogo služabnika političnih interesov, ker je to $\mathrm{v}$ nasprotju $z$ njegovim pesniškim poslanstvom, obenem pa nekako obupava, ker se jasno zaveda, kako utemeljeno je retorično vprašanje o tem, kakšen je sploh smisel puhlih zakonov brez nravstvenih temeljev. Mecenata sprašuje, zakaj ga tako vztrajno sili, naj se vrže v šimo morje tiste poezije, ki ji ni kos, ki ga ne privlači, tako kot se tudi njegovi barčici ne prilegajo velikanska jadra. $^{18}$ Sam želi, kot pravi, po Mecenatovem zgledu pluti po rečici, ne po oceanu. ${ }^{19}$ Vendar so ti njegovi ugovori zgolj zadnji vzdihljaji pred porazom. Da se namerava Propercij dejavno spoprijeti $z$ opravili angažiranega pesnika, dokazujejo popustljive besede $v$ naslednjih verzih ${ }^{20}$ : opeval bo rimske bike na Palatinu, mestno obzidje, ki ga je učvrstil Remov umor, in dvojčka, ki ju je dojila zver, njegov pesniški navdih pa se bo vzpenjal $\mathrm{v}$ višave, kot je zaukazal Mecenat! ${ }^{21}$ Propercij je zdaj kljub vsemu vendarle pripravljen opevati rimsko zgodovino in vse nedotakljive ideale, ki bi morali biti po mnenju velikega reformatorja Avgusta norma vsakega dejanja in vsake misli slehernega rimskega državljana. In če je še v obdobju republike vmešavanje države $\mathrm{v}$ zasebne zadeve veljalo za nedopustno (tudi Cicero zahteva, naj država ostane izven domov državljanov), je v tej pesmi tudi Propercij očitno dojel, da kot uveljavljen pesnik in Mecenatov prijatelj $v$ Avgustovem času ne more več ostajati povsem na robu političnega dogajanja. Postavlja le en pogoj: to je pripravljen početi le pod Mecenatovim vodstvom, te duce $e^{22}$, kot pravi. Seveda ima Propercij svoje razloge za takšno odločitev. Ob koncu pesmi namreč napove izid četrte knjige svojih elegij in se Mecenatu priporoči, naj mu še naprej stoji ob strani. Še več, z njim sklene nekakšno zavezništvo: o meni bodo govorili, da sem stal v tvojih vrstah, zaključuje ${ }^{23}$.

Adde, quod insidiae sacris a vatibus absunt,

et facit ad mores ars quoque nostra suos.

Nec nos ambitio, nec amor nos tangit habendi:

contempto colitur lectus et umbra foro.

${ }^{18}$ Prop., 3, 9, 3-4.

${ }^{19}$ Ibid., 35-36.

${ }^{20}$ Ibid., 47 sq.: Te duce vel Iovis arma canam caeloque minantem Coeum Phlegraeis Eurymedonta iugis; celsaque Romanis decerpta palatia tauris ordiar et caeso moenia firma Remo eductosque pares silvestri ex ubere reges, crescet et ingenium sub tua iussa meum!

Prosequar et currus utroque ab litore ouantis, Parthorum astutae tela remissa fugae castraque Pelusi Romano subruta ferro Antonique gravis in sua fata manus.

${ }^{21}$ Ibid., 53: crescet et ingenium sub tua iussa meum!

22 Ibid., 47 .

23 Ibid., 57-60: Mollis tu coeptae fautor cape lora iuventae dexteraque immissis da mihi signa rotis.

Hoc mihi Maecenas, laudis concedis et a te est quod ferar in partis ipse fuisse tuas. 
Pretirano bi bilo, če bi trdili, da se je Propercij s temi besedami, ko je pristal na sodelovanje pri uveljavitvi Avgustovega političnega programa, odrekel ljubezenski elegiji in se sprijaznil z zahtevami, ki jih je nanj sicer naslavljal prijatelj Mecenat, čeprav Mecenat tega zanesljivo ni počel izključno na lastno pobudo. Zanesljivo pa lahko iz vsebine četrte knjige Propercijeve pesniške zbirke sklepamo, da je bilo že v Propercijevem času zelo težko vztrajati na okopih rimske ljubezenske elegije kot pesniške zvrsti, $\mathrm{ki} v$ takratni politični konstelaciji kljub Avgustovi skrbno načrtovani naklonjenosti do kulture nikakor ni sodila $\mathrm{v}$ vladarjev program moralne prenove. Lahko domnevamo, da je ljubezenska elegija tako zastavljen program, kot so si ga ob vseh velikih pričakovanjih zamislili njegovi sestavljalci, s svojimi ustaljenimi vsebinskimi vzorci kazila in po mnenju nekaterih celo nekoliko ogrožala.

Vprašanje je, zakaj je Propercij sprejel odločitev, da se v četrti knjigi posveti predvsem opevanju rimske tradicije in starožitnosti. Razlogov je lahko več. S precejšnjo verjetnostjo lahko predvidevamo, da se je po dolgotrajnih prošnjah prijatelju Mecenatu le pustil preprositi, naj stopi $\mathrm{v}$ "njegove" vrste (in partes tuas). Morda pa je šlo pri vsem tem tudi za kanček oportunizma kot odziv na vztrajne zahteve uglednega prijatelja in vladarjevega svetovalca. Morda se je celo Propercij sam, pa četudi elegik, zgražal nad razvratnim načinom življenja v Rimu, ki gotovo ni bilo le plod pesniške domišljije, in še zlasti nad njegovimi posledicami, na katere ga je nedvomno opozarjal Mecenat. Morda so bile vmes obljube, mogoče celo kaj drugega. Danes o tem ugibamo zaman. Ostaja pa dejstvo, da je bila rimska ljubezenska elegija $v$ svojem času v popolnem vsebinskem nasprotju z Avgustovimi zamislimi o osvežitvi rimske kulturne in demografske politike s tradicionalnimi vrednotami in da je bila med Rimljani tako priljubljena ljubezenska elegija $v$ svojem času in takratnih političnih razmerah poezija "non grata".

\section{SUMMARY}

In considering why Propertius in the fourth book of his elegies renounced to write love poetry, gave up his "love struggle" and began to celebrate the Roman history in his elegiacs, it is possible to ascertain that the political circumstances at his time were not in favour of Roman elegy. Augustus was striving to enforce his restrictive moral legislation which prevented Roman citizens to marry in compliance with their feelings. Roman love elegy was in contradiction with the Augustus' aims to restore the Roman state with the new demographical politics and to revive the old honest mores maiorum. It is obvious that Propertius in his verses was obliged to celebrate the origin of Rome to support the Augustus' moral reform and that Roman love elegy had a short future because of this political constellation. 